\title{
Endozoochory by native and exotic herbivores in dry areas: consequences for germination and survival of Prosopis seeds
}

\author{
Claudia M. Campos ${ }^{1 *}$, Begoña Peco², Valeria E. Campos ${ }^{3}$, Juan E. Malo², \\ Stella M. Giannoni ${ }^{3}$ and Francisco Suárez ${ }^{2}$ \\ ${ }^{1}$ Grupo de Investigaciones de la Biodiversidad, IADIZA-CONICET, Argentina; ${ }^{2}$ Departamento de Ecología, \\ Universidad Autónoma de Madrid, Spain; ${ }^{3}$ Museo de Ciencias Naturales, Universidad Nacional de San Juan, \\ Argentina
}

\begin{abstract}
Mammalian herbivores can play a role in the endozoochorous dispersal of Prosopis seeds in the arid zones of Argentina, and the introduction of exotic mammals can change relevant parameters of the plant's reproductive ecology. Our specific goals were to quantify the seeds of Prosopis flexuosa, P. chilensis and $P$. torquata contained in the faeces of native [mara (Dolichotis patagonum), guanaco (Lama guanicoe)] and exotic [donkey (Equus asinus) and hare (Lepus europaeus)] mammals, and to determine the mortality, germination percentage and germination speed of seeds borne in faeces, compared with those collected from trees. In 2006, seeds were collected directly from trees or removed from mammal faeces. Seeds were counted and classified as apparently healthy or damaged. P. torquata and P. flexuosa seeds were found in the dung of guanaco, hare and mara, whereas only $P$. flexuosa seeds appeared in donkey faeces. $P$. chilensis seeds were only found in guanaco faeces. There was a notable relative abundance of seeds contained in small herbivore faeces in comparison to the large herbivores. The passage through the digestive tract of animals modified seed germination capacity and speed, with great variability between animal species. Guanacos had greater effects than donkeys on mortality, germination percentage and germination speed. Differences between the effects of both smaller-sized herbivores on seeds were much smaller.
\end{abstract}

Keywords: Argentina, desert, donkey, guanaco, hare, Ischigualasto, mara, mesquite, Prosopis

*Correspondence

Email: ccampos@lab.cricyt.edu.ar

\section{Introduction}

Biological processes, such as endozoochory, involve the ingestion of seeds and their passage through the animal digestive tract. Seeds can be scarified, increasing germination speed, although the mortality potential increases if the seed coats weaken too much (Janzen et al., 1985). These effects of herbivory are related to digestion, the gut retention period, seed size and the hardness of seed coats according to the maturity stage of propagules, etc. (Janzen, 1981, 1982; Janzen et al., 1985). However, enhanced germination of seeds following passage through the herbivore gut may not always be beneficial (Traveset and Verdú, 2002).

The effect of endozoochorous dispersers on seeds also depends on their final destination. On the one hand, seed transport is beneficial for the plant by allowing it to occupy new environments (colonization hypothesis; Howe and Smallwood, 1982) and to reduce predation risk, parasitism and competition near the mother plant (escape hypothesis; Janzen, 1970; but see Hyatt et al., 2003). In some cases faeces can also provide a propitious environment for germination (Gokbulak and Call, 2004). However, final seedling establishment is not ensured, because it depends on seedling and seed predation in the faeces, the suitability of the defecation site for seedlings, sibling competition for resources and the current environmental conditions (Janzen, 1981; Howe, 1986). In view of the complexity of factors involved in endozoochory, it is not surprising that the effects of seed dispersal are sometimes contradictory, with frequent variations between different sites, plants and herbivore species (Traveset and Verdú, 2002; Verdú and Traveset, 2005).

Exotic species can disrupt mutualistic plantanimal interactions such as seed dispersal (Traveset and Riera, 2005). When seed dispersal is a limiting factor, they can be effective seed dispersers of many 
native plants, but they can also have a detrimental effect if they compete with native dispersers and/or modify either the seed shadow or the germination patterns generated by native dispersers (see review by Traveset and Richardson, 2006).

In the semi-arid areas of Argentina, species of the genus Prosopis (Fabaceae) play an important role in the functioning of plant and animal communities. Prosopis acts as an environmental stabilizer and yields a variety of useful products for rural populations. This genus maintains ecosystem complexity by creating microhabitats and is a valuable food resource for both humans and animals (Kingsolver et al., 1977; Mares et al., 1977; Or and Ward, 2003; Rossi and Villagra, 2003). Domestic and wild herbivores can play a role in the endozoochorous dispersal of Prosopis seeds (e.g. Eilberg, 1973; Peinetti et al., 1992, 1993; Campos and Ojeda, 1997; Ortega Baes et al., 2002; Kneuper et al., 2003). In this interaction, seeds can lose viability and be subject to different effects on germinability, depending on the particular mammal and Prosopis species involved. Results of studies of $P$. ruscifolia, $P$. caldenia and $P$. ferox consider that in animals, such as cows, goats and donkeys, gut passage is not an important means of seed release from dormancy, and therefore endozoochory may not increase germination percentages (Eilberg, 1973; Peinetti et al., 1992; Ortega Baes et al., 2002). However, when other mammals (horses, wild mammals) participate in endozoochory, germination percentages increase significantly ( $P$. ruscifolia, $P$. caldenia, $P$. flexuosa, P. glandulosa; Eilberg, 1973; Peinetti et al., 1993; Campos and Ojeda, 1997; Kneuper et al., 2003). Therefore, the introduction of exotic herbivores may change Prosopis dispersal processes, with potential effects on the function of plant communities in the Monte desert where these species play a major role.

In this context, our specific goals were: (1) to quantify the $P$. flexuosa, $P$. chilensis and $P$. torquata seeds contained in the faeces of native (mara and guanaco) and exotic mammals (donkey and hare); and (2) to determine mortality, germination percentage and germination speed of faeces-borne seeds compared to those collected directly from trees.

\section{Materials and methods}

\section{Study site}

The study was conducted in the Ischigualasto Provincial Park $\left(29^{\circ} 55^{\prime} \mathrm{S}, 68^{\circ} 05^{\prime} \mathrm{W}\right), 335 \mathrm{~km}$ from San Juan city, Valle Fértil Department, at $1300 \mathrm{~m}$ above sea level. The region has a desert climate, a wide day/night temperature range, summer rains below $100 \mathrm{~mm}$ per year, $-10^{\circ} \mathrm{C}$ absolute minimum in winter and $45^{\circ} \mathrm{C}$ absolute maximum in summer.
Approximately $90 \%$ of the area is part of the Monte phytogeographical province, with small sectors in the Chaco Serrano and the Cardonal districts (Acosta and Murúa, 1999; Márquez, 1999). The predominant physiognomy is open scrubland, with heavy soil and moisture limitations on the plant communities (Márquez, 1999).

Some of the analysed mammalian species have conservation problems due to their restricted geographic distribution and low population densities. Moreover, available information is quite scarce, as in the case of mara (Dolichotis patagonum), a hystricognath rodent ranked as requiring 'special attention' (Acosta and Murúa, 1999) and 'vulnerable' (Diaz and Ojeda, 2000), and guanaco (Lama guanicoe), ranked as 'potentially vulnerable' (Diaz and Ojeda, 2000). Although it has a wide distribution and flexibility in its use of food resources, guanaco populations are under heavy pressure from poaching and the introduction of alien species (Puig et al., 2001). Recently, the guanaco population in Ischigualasto has been given the 'highest conservation priority' (Acosta and Murúa, 1999). In addition, the Park supports exotic species, such as donkey (Equus asinus) and hare (Lepus europaeus), whose interactions with vegetation and native mammals are virtually unknown.

\section{Seed and faeces collection}

Prosopis fruit is a modified indehiscent legume with a thin epicarp, a mesocarp that can be fleshy, sugary or fibrous and several endocarp segments (Burkart, 1976). Prosopis germination is hindered by physical dormancy (Bewley and Black, 1982; Peinetti et al., 1993), and seed scarification by different agents increases germination (Catalán and Balzarini, 1992; Peláez et al., 1992; Peinetti et al., 1993; Ortega Baes et al., 2002).

Between January and April 2006, we collected seed samples of 10 fruits per tree directly from 9, 10 and 11 $P$. flexuosa, $P$. chilensis and $P$. torquata trees, respectively (henceforth tree seeds). During this period, we also collected fresh independent samples of faeces of exotic (donkey and hare) and native mammals (mara and guanaco). Independent faeces samples were defined as those more than $2 \mathrm{~m}$ apart for small mammals or $100 \mathrm{~m}$ for large mammals. The samples were collected in the habitats used most heavily by the herbivores within a roughly $200 \mathrm{~km}^{2}$ area.

We counted the Prosopis spp. seeds in a total of $574 \mathrm{~g}$ of air-dried faeces for mara, $1298 \mathrm{~g}$ for guanaco, $32.8 \mathrm{~g}$ for hare and $1300 \mathrm{~g}$ for donkey, taken from 100, 26, 15 and 13 independent samples, respectively. The seeds were classified as apparently healthy (with and without endocarps) or damaged, based on 
observations of external traits. Insect-damaged seeds (presence of insect exit holes) were counted separately from those with other damage (broken by chewing, open endocarps with malformed seed, etc.).

\section{Germination experiments}

During July 2006, germination tests were performed in incubators (Precision GCA Corporation, Scientific Model 818, Chicago, Illinois, USA) with constant light and temperature $\left(30^{\circ} \mathrm{C}\right)$, using $9-\mathrm{cm}$ diameter Petri dishes prepared with sand moistened to saturation. Mortality, germination percentage and germination speed were measured for seeds taken from trees (control seeds) and for seeds from herbivore faeces.

We used visually healthy P. flexuosa, P. chilensis and $P$. torquata seeds with endocarps collected from trees (two 25-seed replicates for each tree). In the case of $P$. flexuosa, two seed lots were used, with and without endocarps, as seeds in both conditions appeared in the faeces. Apparently healthy seeds collected from herbivore droppings were also cultivated, with sample sizes determined by seed availability. Thus, $P$. flexuosa seeds were found in mara faeces and donkey dung (16 replicates of 25 seeds used for each herbivore), hare (3 replicates of 25 seeds each) and guanaco (4 replicates of 25 seeds: 3 replicates of seeds without endocarp and 1 replicate of seeds with endocarp). $P$. chilensis seeds were found only in guanaco faeces (16 replicates of 25 seeds each). $P$. torquata seeds were taken from mara and guanaco faeces (16 replicates of 25 seeds for each herbivore) and hare faeces ( 3 replicates of 25 seeds).

\section{Germination percentage and speed}

To define the percentage of viable seeds, seeds that had not germinated in the previous experiment were manually scarified and placed under the abovementioned conditions for $14 \mathrm{~d}$. Scarified seeds that did not germinate after this period were subjected to the standard treatment with a 2,3,5-triphenyltetrazolium chloride test (Pili-Sevilla, 1987), which detects seed viability by staining the embryo tissue pink/red.

Germination percentage was the number of germinated seeds in relation to the number of viable seeds known at the end of the trials. Seed mortality was obtained from the number of non-viable seeds in the tests, plus the number of damaged seeds (parasitized by insects, malformations, affected by herbivores, etc.) in relation to the number of seeds in the lots.

Seed germination speed was estimated for all seed sources, and the weighted germination percentage (germination speed) index was calculated for a $21 \mathrm{~d}$ period (Reddy et al., 1985). This index gives maximum weight to the seeds that germinate first and a decreasing weight to subsequent germination. It is computed as follows:

$$
\text { Germination speed }=\frac{21 n_{1}+19 n_{3}+\cdots+1 n_{21}}{21 N} \times 100
$$

where $n_{1}, n_{3}, \ldots, n_{21}=$ number of seeds germinated on the first, third,..., twenty-first day, and $N=$ total number of seeds. The value for germination speed varies between 100 (if all seeds germinate on the first day) and 0 (when none germinate in the study period).

\section{Statistical analysis}

The Kruskal-Wallis test was used to compare mortality, germination percentage and germination speed among seeds from different sources, due to the lack of normality in these variables. Post hoc comparisons were performed using the MannWhitney test (Zar, 1984) with the sequential Bonferroni correction (Rice, 1989). All statistical analyses were performed with SPSS 13.0 (SPSS Corp., Chicago, Illinois, USA).

\section{Results}

P. torquata and P. flexuosa seeds were found in guanaco, hare and mara dung, whereas only P. flexuosa seeds appeared in donkey faeces (Table 1). P. chilensis seeds were found only in guanaco faeces. In general, small herbivore faeces contained higher total densities of Prosopis seeds than those of the large herbivores (4-5 seeds $\mathrm{g}^{-1}$ versus $1-2$ seeds $\left.\mathrm{g}^{-1}\right)$.

Table 1 shows that $P$. torquata seeds in dung were generally embedded within their endocarps; however, small numbers without endocarp were found in mara and guanaco dung. In the case of P. flexuosa, most seeds occurring in the faeces of mara, hare and donkey were enclosed inside their endocarps. Seeds of $P$. chilensis only appeared in guanaco dung and they lost their endocarps during gut passage.

A surprisingly large number of damaged seeds were found in the faeces of guanaco (for $P$. torquata and $P$. chilensis) and donkey (P. flexuosa). Insect damage seemed to be particularly frequent in $P$. chilensis seeds contained in guanaco dung (Table 1).

\section{Seed mortality}

The mortality for $P$. torquata seeds differed significantly between groups $(K=34.07, P<0.001$, Fig. 1 a). Seeds in guanaco faeces exhibited the highest 
Table 1. Seed content (mean \pm SE) of Prosopis species in the faeces of the four herbivores studied. The detected seeds were classified by appearance as healthy (with or without endocarp) or damaged (see text). Data show seeds/10 g of dung, with the relative percentage of each seed class for each species of Prosopis and herbivore shown in parentheses

\begin{tabular}{|c|c|c|c|c|}
\hline & Mara $(N=100)$ & Guanaco $(N=26)$ & Hare $(N=15)$ & Donkey $(N=13)$ \\
\hline \multicolumn{5}{|l|}{ P. torquata } \\
\hline With endocarp & $26.45 \pm 2.02(93.56)$ & $4.58 \pm 1.39(81.93)$ & $28.65 \pm 6.79(94.46)$ & \\
\hline Without endocarp & $0.02 \pm 0.01(0.07)$ & $0.02 \pm 0.01(0.36)$ & & \\
\hline Damaged by insects & $1.55 \pm 0.38(5.48)$ & $0.03 \pm 0.02(0.54)$ & $0.51 \pm 0.51(1.68)$ & \\
\hline Damaged by other causes & $0.25 \pm 0.08(0.88)$ & $0.96 \pm 0.33(17.17)$ & $1.17 \pm 0.68(3.86)$ & \\
\hline \multicolumn{5}{|l|}{ P. chilensis } \\
\hline \multicolumn{5}{|l|}{ With endocarp } \\
\hline Without endocarp & & $10.63 \pm 4.28(69.25)$ & & \\
\hline Damaged by insects & & $4.64 \pm 1.74(30.23)$ & & \\
\hline Damaged by other causes & & $0.08 \pm 0.05(0.52)$ & & \\
\hline \multicolumn{5}{|l|}{ P. flexuosa } \\
\hline With endocarp & $13.69 \pm 1.47(82.42)$ & $0.22 \pm 0.08(20.37)$ & $16.97 \pm 5.89(77.10)$ & $11.80 \pm 3.54(54.26)$ \\
\hline Without endocarp & $0.43 \pm 0.16(2.58)$ & $0.70 \pm 0.34(64.81)$ & $1.23 \pm 0.97(5.59)$ & $0.13 \pm 0.09(0.60)$ \\
\hline Damaged by insects & $0.99 \pm 0.25(5.96)$ & $0.05 \pm 0.04(4.63)$ & $0.45 \pm 0.31(2.04)$ & $4.37 \pm 1.00(20.09)$ \\
\hline Damaged by other causes & $1.50 \pm 0.26(9.03)$ & $0.11 \pm 0.04(10.18)$ & $3.36 \pm 1.16(15.26)$ & $5.45 \pm 1.57(25.06)$ \\
\hline
\end{tabular}

mortality compared to control seeds, seeds in hare droppings and seeds in mara faeces. The latter three groups showed no significant differences. $P$. chilensis seed mortality was significantly higher in seeds dispersed by guanaco than in control seeds $(U=12.5, P<0.001$, Fig. 1b). Mortality for $P$. flexuosa seeds with endocarps showed significant differences between groups $(K=18.12, P=0.001$, Fig. 1c). Seeds collected from donkey dung exhibited the highest mortality, differing from seeds dispersed by mara and from control seeds. Seeds contained in mara faeces also showed a significantly higher mortality than control seeds, whereas seeds dispersed by hare showed no statistical differences from the other groups. Mean mortality for seeds found in guanaco faeces was generated by only one replicate of 25 seeds, thus preventing comparisons between this and the other groups. The mortality of seeds without endocarps was significantly higher in seeds dispersed by guanaco $(U=6.39, P=0.011$, Fig. $1 d)$ than in control seeds.

\section{Germination percentage}

For $P$. torquata, germination percentage showed no significant differences between groups $(K=5.64$, $P=0.130$, Fig. 2a). In the case of $P$. chilensis, germination percentage was significantly higher in seeds dispersed by guanaco than in control seeds $(U=9, P<0.001$, Fig. 2b). For $P$. flexuosa seeds with endocarps, germination percentages showed only marginal differences between groups $(K=8.17$, $P=0.08$, Fig. 2c). Nonetheless, post hoc comparisons showed a higher germination percentage in seeds dispersed by hare than in those dispersed by mara. No significant differences were found in any other comparisons. P. flexuosa seeds without endocarps from guanaco faeces showed a higher germination percentage than the control seeds $(U=0, P=0.013$, Fig. 2d).

\section{Germination speed}

Germination speed for $P$. torquata was significantly different among groups ( $K=18.2, P<0.001$, Fig. 3a). Seeds contained in guanaco faeces germinated more slowly than those from mara or hare faeces, but not control seeds. Seeds found in faeces of small herbivores showed a significantly higher germination speed than control seeds. $P$. chilensis germination speed was significantly higher in seeds dispersed by guanaco than in control seeds $(U=10, P<0.001$, Fig. 3b). For P. flexuosa seeds with endocarps, germination speed showed differences between groups $(K=9.69, P=0.046$, Fig. 3c). Seeds dispersed by hare showed a higher germination speed than seeds dispersed by donkeys and control seeds. Finally, $P$. flexuosa seeds without endocarps taken from guanaco faeces presented a higher germination speed than control seeds $(U=3, P=0.05$, Fig. $3 \mathrm{~d})$.

\section{Discussion}

All herbivores dispersed the seeds of one or more Prosopis species through their faeces, and in some cases, the passage of seeds through the animal gut modified their germinability. This is also the first record of dispersal by herbivores of $P$. torquata and $P$. chilensis, two significant species in the arid zones of Argentina (Burkart, 1976). 
(a)

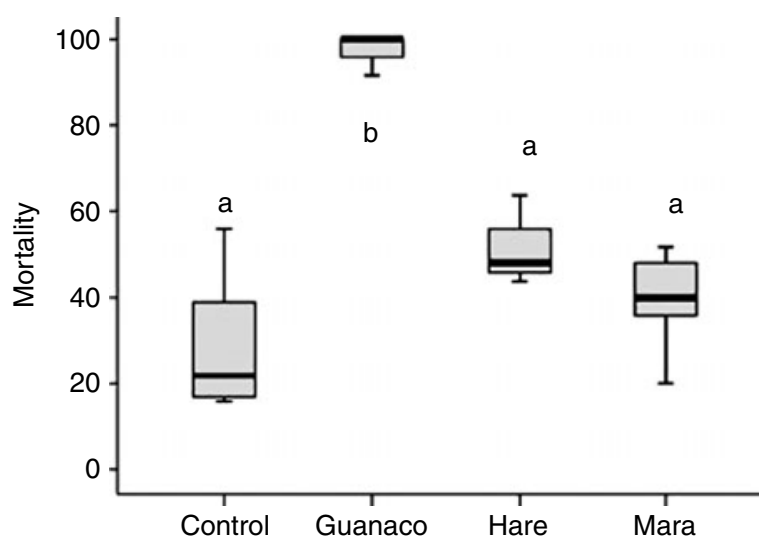

(c) (b)

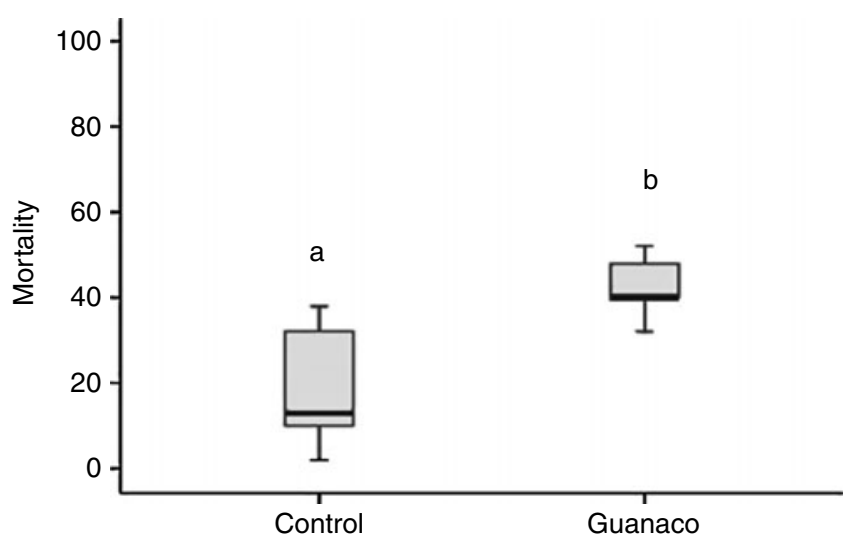

(d)

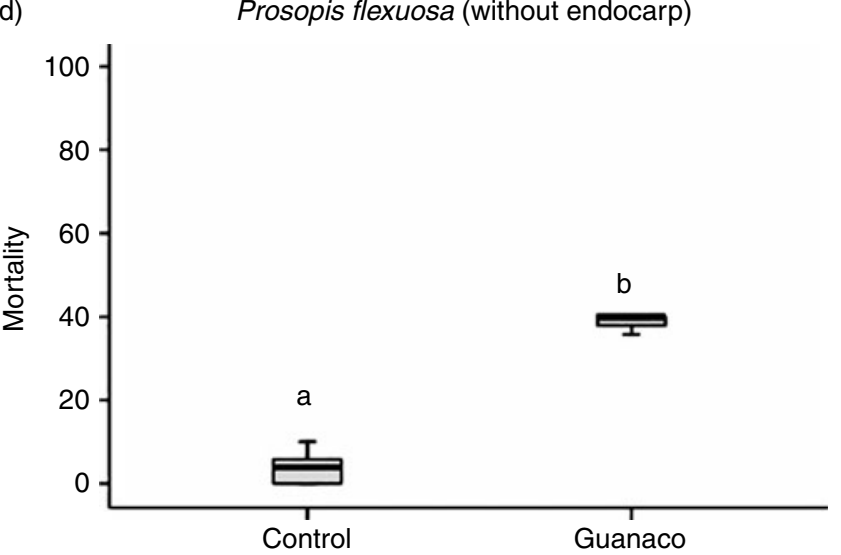

Figure 1. Mortality of seeds (number of dead seeds/number of seeds in lots of 100 seeds) taken from trees (control) and dung of different herbivores for Prosopis torquata, P. chilensis and P. flexuosa (without endocarp and with endocarp). In this and other figures, different letters indicate significant differences between groups (control, donkey, guanaco, hare and mara) after correction for multiple testing (Rice, 1989). Each box shows the range between 25th and 75th percentiles; the central line shows the median. Vertical bars represent the highest and lowest values that are not outliers or extreme values.

\section{Seeds in faeces}

Considerable numbers of Prosopis seeds were found in the faeces of the four analysed small- and large-sized herbivores. Although this has been found on several occasions for various herbivore species (e.g. Campos and Ojeda, 1997; Kneuper et al., 2003; Varela, 2004), the present study is the first one to highlight differences between herbivores, with a special focus on the native versus exotic effect in an extremely arid protected area.

P. torquata and P. flexuosa seeds were found in high and similar densities in the faeces of the two smallest species. Studies of the trophic ecology of these herbivores show that their behaviour is opportunistic in the consumption of Prosopis spp. fruits, when available in large quantities (Campos, 1997; Campos et al., 2001).
Major differences were found in larger herbivores, with a notable presence of all three Prosopis species in guanaco faeces, as opposed to the occurrence of only $P$. flexuosa in donkey dung. This undoubtedly reflects the use of a wide diversity of environments by guanacos and their browsing behaviour (Puig et al., 1997, 2001), in contrast to donkeys, which have a feeding strategy that is closer to that of bulk grazers and tend to concentrate around ephemeral watercourses (Lamoot et al., 2005; Acebes et al., unpublished).

Large percentages of damaged seeds were detected in animal faeces, especially in the cases of guanaco (P. torquata $18 \%$ and $P$. chilensis $31 \%$ ) and donkey (P. flexuosa $45 \%$ ). Taking only insect damage into account, $P$. chilensis seeds are seriously affected in guanaco faeces (30\%) as are P. flexuosa seeds in donkey dung $(20 \%)$. The insect damage data should be used with caution and considered as estimates of the 
(a)

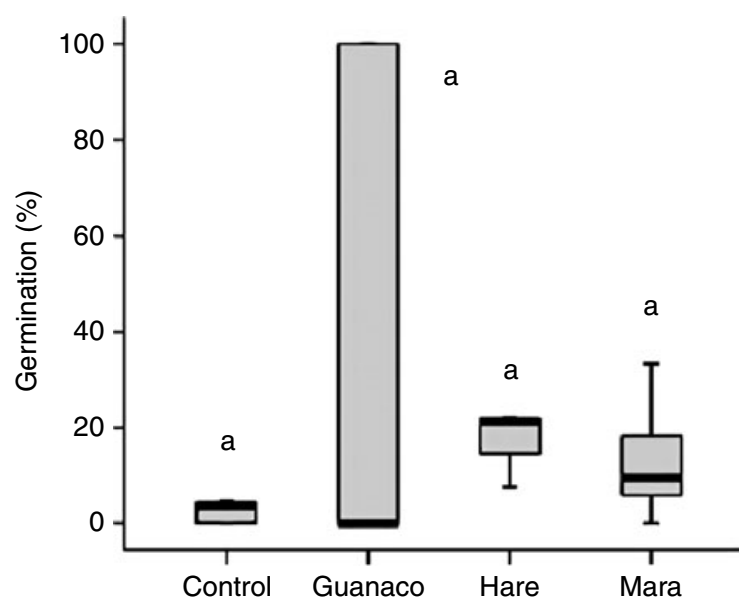

(c)

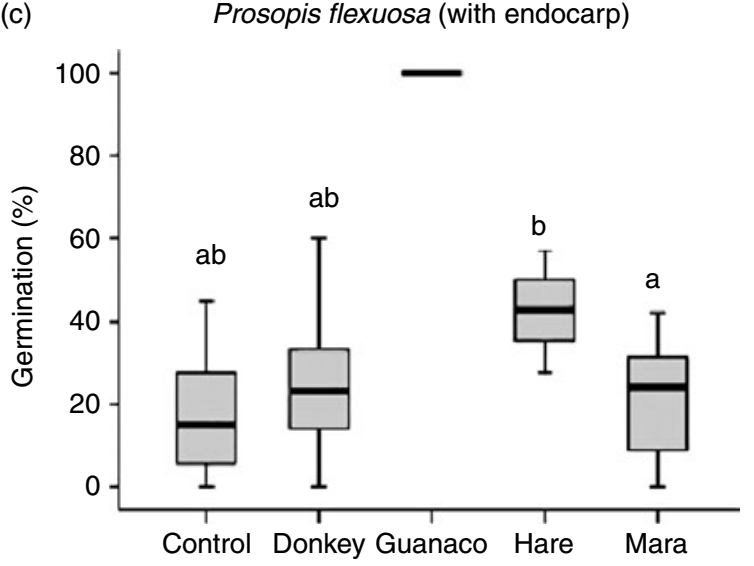

(b)
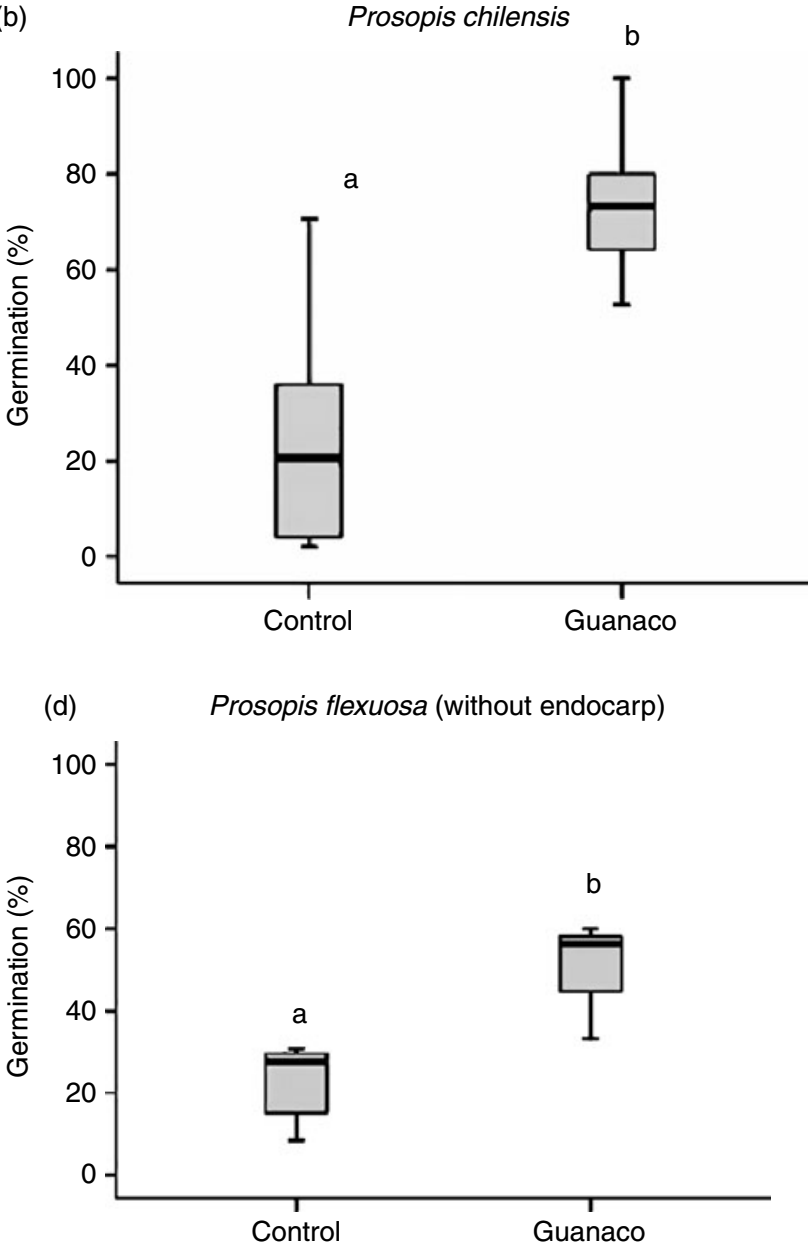

Figure 2. Germination percentages of seeds taken from trees (control) and dung of different herbivores for Prosopis torquata, P. chilensis and P. flexuosa (without endocarp and with endocarp). Symbols as in Fig. 1.

minimum number of damaged seeds; they are taken from external observations of holes in the endocarp produced by the emergence of adult insects, while seeds affected by larvae of arthropods and by plant infections were not quantified. This observation matches studies of the Prosopis genus that show predation by bruchids is high in both pods in trees (Smith and Ueckert, 1974; Kingsolver et al., 1977) and pods in the soil (Lerner and Peinetti, 1996; Ortega Baes et al., 2001), although our study did not reveal when the seeds were infected. With respect to the number of seeds damaged by other causes, we found a large number in guanaco faeces for P. torquata $(17 \%)$ and in donkey faeces for P. flexuosa (25\%). High percentages of death among seeds ingested by large herbivores could be associated with the long duration of gut passage, but differences across plant species found in any animal dung are more difficult to interpret, and may be related to pod traits such as dryness.

\section{Mortality, germination percentage and speed}

Seed mortality increased following passage through the animal gut, particularly in the case of the two largest herbivores. The change was significant in all cases with the guanaco, increasing in the most extreme situation from 20 to $100 \%$ (medians for P. torquata seeds). Similarly, passage through the donkey digestive tract increased the mortality of $P$. flexuosa seeds from 28 to $48 \%$, contrary to the results of Ortega Baes et al. (2002), who found no effect from consumption by donkey on the viability of P. ferox seeds compared to seeds taken from plants.

Among the smallest herbivores, only passage through the mara digestive tract increased mortality in P. flexuosa seeds with endocarps, in comparison with control seeds. In a previous study in the Monte desert (Ñacuñán Reserve, Mendoza Province), mortality due to endozoochory by rodents such as mara 


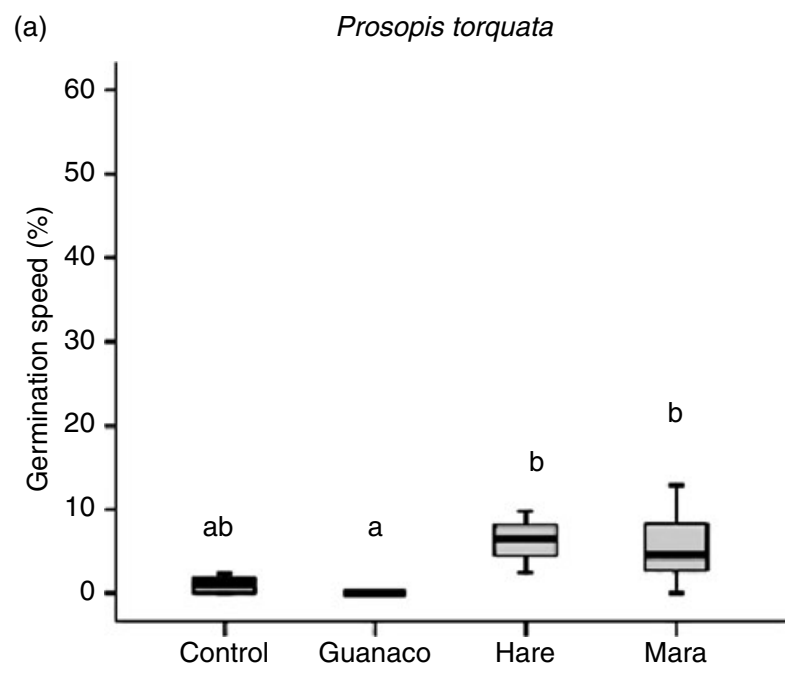

(b) Prosopis chilensis
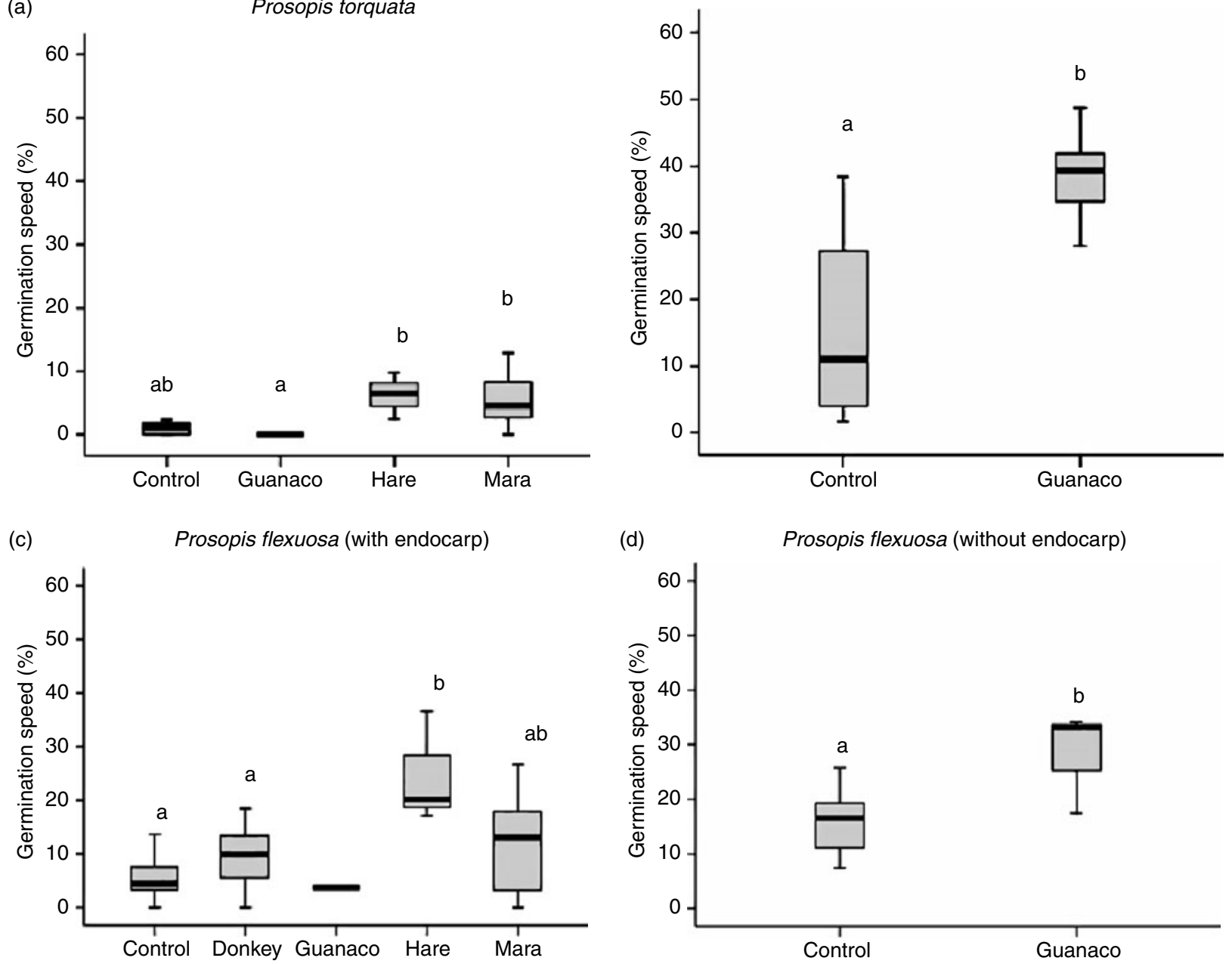

Figure 3. Germination speed (\%) for seeds taken from trees (control) and dung of different herbivores for Prosopis torquata, P. chilensis and P. flexuosa (without endocarp and with endocarp). Symbols as in Fig. 1.

was roughly $30 \%$ (Campos and Ojeda, 1997), similar to the results of the present study.

Regarding percentage and speed of germination, comparisons between large herbivores showed that guanaco had larger effects on seeds than donkey, which did not increase either parameter. The low response of passage through the donkey digestive tract is consistent with studies that suggest that intake of Fabaceae pods by domestic herbivores (cattle, goat and donkey) does not appear directly to improve seed germinability in some Prosopis species (P. ruscifolia, $P$. caldenia and $P$. ferox), in comparison with healthy seeds scarified by mechanical or chemical means (Eilberg, 1973; Peinetti et al., 1992, 1993; Ortega Baes et al., 2002; Kneuper et al., 2003). However, the guanaco significantly increased the germinable proportion and germination speed of $P$. chilensis seeds and P. flexuosa without endocarps, although it did not seem to alter these parameters in $P$. torquata seeds. Moreover, in the case of P. flexuosa, the seeds found in the faeces had been freed of their endocarps.

Among the smaller herbivores, few effects on germination percentage and speed were detected. Only hare seemed to increase the germination percentage of $P$. flexuosa seeds with endocarps. Previous studies did not find any effect of hare gut passage on germination (Izhaki and $\mathrm{Ne}^{\prime}$ eman, 1997), although the lack of effects may be due to the comparisons having been made between seeds from hare faeces and manually scarified seeds. However, in the Monte desert (Ñacunán Reserve, Mendoza Province), medium-sized rodents, such as mara, disperse $P$. flexuosa seeds with endocarps and enhance their germination capacity (Campos and Ojeda, 1997). 
The effects of herbivore gut passage on Prosopis seed survival and germinability are multiple and differentiated between plant species and animal dispersers. Large variability in seed germination capacity and speed after gut passage is usually found in comparisons of endozoochory by different animal species (for reviews see Traveset, 1999; Traveset and Verdú, 2002; Verdú and Traveset, 2005). In our case, this variability was both direct, in terms of survival and germinability, and indirect, via the deposition of a percentage of the seeds released from the endocarp ( $P$. flexuosa in guanaco faeces). In this case, gut passage partially released seeds from the physical dormancy imposed by hard impermeable seed coats and should facilitate subsequent environmental scarification by soil abrasion or extreme temperature cycles (Janzen, 1981; Izhaki and Ne'eman, 1997; Ortega Baes et al., 2002). In any case, removal of $P$. flexuosa pods by animals should not be described just as a mechanism for seed loss (Villagra et al., 2002; Milesi and López de Casenave, 2004; Campos et al., 2007), since part of the removed seeds can remain viable and may give rise to the establishment of new plants. The final effect on the plant species depends on the costs associated with the loss of seeds through animal ingestion and digestion, and the effect of seed predators and environmental conditions for germination and establishment on the fate of dispersed seeds (Howe and Smallwood, 1982; Maron and Gardner, 2000). Our data show changes in the seed availability and germinability parameters that determine this final effect, thus introducing the possibility of differential changes in Prosopis spp. recruitment linked to the presence of alien herbivores.

Finally, when evaluating the results, we must bear in mind that the experimental conditions can have consequences for the detected effects on the seeds (Rodríguez-Pérez et al., 2005; Samuels and Levey, 2005; Robertson et al., 2006; Traveset et al., 2007). To minimize this problem in the present study, we compared seeds from trees and from faeces not released from endocarps, finding that germinability of control seeds was lower than in previous laboratory studies. However, in many experiments the effect on germinability is measured by comparing dung-borne seeds with healthy control seeds that have been scarified by mechanical or chemical means, which is optimal for breaking dormancy and maximizing germination under laboratory conditions (e.g. Catalán and Macchiavelli, 1991; Catalán and Balzarini, 1992; Cony and Trione, 1996; Ortega Baes et al., 2002).

In conclusion, although the directionality of changes associated with the presence of exotic herbivores is not easy to determine, there is a clear differential effect across herbivores on Prosopis spp. seed endozoochory and germination. Moreover, for the two analysed pairs of herbivore species, changes linked to dispersal in dung by hare in comparison to mara are smaller than those associated with endozoochory by donkey versus guanaco.

\section{Acknowledgements}

This research was funded by BBVA Foundation (INTERMARG Project). The Argentine authors are CONICET researchers and fellows. We thank the staff at the Ischigualasto Provincial Park for their support. Nélida Horak and Jamie Benyei assisted us in drafting the English version.

\section{References}

Acosta, J.C. and Murúa, F. (1999) Lista preliminar y estado de conservación de la mastofauna del Parque Natural Ischigualasto, San Juan - Argentina. Multequina 8, 121-129.

Bewley, J.D. and Black, M. (1982) Physiology and biochemistry of seeds in relation to germination. Vol. 1. New York, Springer.

Burkart, A. (1976) A monograph of the genus Prosopis (Leguminosae Subfam. Mimosoideae). Journal of the Arnold Arboretum 57, 219-249.

Campos, C.M. (1997) Utilización de recursos alimentarios por mamíferos medianos y pequeños del desierto del Monte. PhD thesis, Universidad Nacional de Córdoba, Argentina.

Campos, C.M. and Ojeda, R.A. (1997) Dispersal and germination of Prosopis flexuosa (Fabaceae) seeds by desert mammals in Argentina. Journal of Arid Environments 35, 707-714.

Campos, C., Ojeda, R., Monge, S. and Dacar, M. (2001) Utilization of food resources by small and medium-sized mammals in the Monte desert biome, Argentina. Austral Ecology 26, 142-149.

Campos, C.M., Giannoni, S.M., Taraborelli, P. and Borghi, C.E. (2007) Removal of mesquite seeds by small rodents in the Monte desert, Argentina. Journal of Arid Environments 69, 228-236.

Catalán, L.A. and Balzarini, M. (1992) Improved laboratory germination conditions for several arboreal Prosopis species: P. chilensis, P. flexuosa, P. nigra, P. alba, P. caldenia and P. affinis. Seed Science and Technology 20, 293-298.

Catalán, L.A. and Macchiavelli, R.E. (1991) Improving germination in Prosopis flexuosa D.C. and P. alba Griseb. with hot water treatments and scarification. Seed Science and Technology 19, 253-262.

Cony, M.A. and Trione, S.O. (1996) Germination with respect to temperature of two Argentinian Prosopis species. Journal of Arid Environments 33, 225-236.

Diaz, G.B. and Ojeda, R.A. (2000) Libro Rojo de Mamíferos amenazados de Argentina. Argentina, SAREM.

Eilberg, B.A. (1973) Presencia de disemínulos de 'vinal' (Prosopis ruscifolia Griseb) en deyecciones de equinos y bovinos. Ecología 1, 56-57.

Gokbulak, F. and Call, C.A. (2004) Grass seedling recruitment in cattle dungpats. Journal of Range Management 57, 649-655. 
Howe, H.F. (1986) Seed dispersal by fruit-eating birds and mammals. pp. 123-189 in Murray, D.R. (Ed.) Seed dispersal. Sydney, Academic Press.

Howe, H.F. and Smallwood, J. (1982) Ecology of seed dispersal. Annual Review of Ecology and Systematics 13, 201-228.

Hyatt, L.A., Rosenberg, M.S., Howard, T.G., Bole, G., Fang, W., Anastasia, J., Brown, K., Grella, R., Hinman, K., Kurdziel, J.P. and Gurevitch, J. (2003) The distance dependence prediction of the Janzen-Connell hypothesis: a meta-analysis. Oikos 103, 590-602.

Izhaki, I. and Ne'eman, G. (1997) Hares (Lepus spp.) as seed dispersers of Retama raetam (Fabaceae) in a sandy landscape. Journal of Arid Environments 37, 343-354.

Janzen, D.H. (1970) Herbivores and the number of tree species in tropical forests. American Naturalist 104, 501-528.

Janzen, D.H. (1981) Enterolobium cyclocarpum seed passage rate and survival in horses, Costa Rican Pleistocene seed dispersal agents. Ecology 62, 593-601.

Janzen, D.H. (1982) Differential seed survival and passage rates in cows and horses, surrogate Pleistocene dispersal agents. Oikos 38, 150-156.

Janzen, D.H., Demment, M.W. and Robertson, J.B. (1985) How fast and why do germinating guanacaste seeds (Enterolobium cyclocarpum) die inside cows and horses? Biotropica 17, 322-325.

Kingsolver, J.M., Johnson, C.D., Swier, S.R. and Terán, A. (1977) Prosopis fruits as a resource for invertebrates. pp. 108-122 in Simpson, B.B. (Ed.) Mesquite: its biology in two desert scrub ecosystems. Stroudsburg, Pennsylvania, Dowden, Hutchinson \& Ross, Inc.

Kneuper, C.L., Scott, C.B. and Pinchak, W.E. (2003) Consumption and dispersion of mesquite seeds by ruminants. Journal of Range Management 56, 255-259.

Lamoot, I., Callebut, J., Demeulenaere, E., Vandenberghe, C. and Hoffmann, M. (2005) Foraging behaviour of donkeys grazing in a coastal dune area in temperate climate conditions. Applied Animal Behaviour Science 92, 93-112.

Lerner, P. and Peinetti, R. (1996) Importance of predation and germination on losses from the seed bank of caldén (Prosopis caldenia). Journal of Range Management 49, 147-150.

Mares, M.A., Enders, F.A., Kingsolver, J.M., Neff, J.L. and Simpson, B.B. (1977) Prosopis as a niche component. pp. 123-149 in Simpson, B.B. (Ed.) Mesquite: its biology in two desert scrub ecosystems. Stroudsburg, Pennsylvania, Dowden, Hutchinson \& Ross, Inc.

Maron, J.L. and Gardner, S.N. (2000) Consumer pressure, seed versus safe-site limitation, and plant population dynamics. Oecologia 124, 260-269.

Márquez, J. (1999) Las Áreas protegidas de la Provincia de San Juan. Multequina 8, 1-10.

Milesi, F.A. and López de Casenave, J. (2004) Unexpected relationships and valuable mistakes: non-myrmecochorous Prosopis dispersed by messy leaf cutting ants in harvesting their seeds. Austral Ecology 29, 558-567.

Or, K. and Ward, D. (2003) Three-way interactions between Acacia, large mammalian herbivores and bruchid beetles - a review. African Journal of Ecology 41, 257-265.

Ortega Baes, P., de Viana, M. and Saravia, M. (2001) The fate of Prosopis ferox seeds from unremoved pods at National
Park Los Cardones. Journal of Arid Environments 48, 185-190.

Ortega Baes, P., de Viana, M.L. and Sühring, S. (2002) Germination in Prosopis ferox seeds: effects of mechanical, chemical and biological scarificators. Journal of Arid Environments 50, 185-189.

Peinetti, R., Cabezas, C., Pereyra, M. and Martinez, O. (1992) Observaciones preliminares sobre la diseminación del caldén (Prosopis caldenia Burk). Turrialba 42, 415-417.

Peinetti, R., Pereyra, M., Kin, A. and Sosa, A. (1993) Effects of cattle ingestion on viability and germination rate of caldén (Prosopis caldenia) seeds. Journal of Range Management 46, 483-486.

Peláez, D.V., Boó, R.M. and Elia, O.R. (1992) Emergence and seedling survival of caldén in the semiarid region Argentina. Journal of Range Management 45, 564-568.

Pili-Sevilla, E. (1987) Germination and tetrazolium testing. Seed Science and Technology 15, 691-698.

Puig, S., Videla, F. and Cona, M.I. (1997) Diet and abundance of the guanaco (Lama guanicoe Muller 1776), in four habitats of Northern Patagonia, Argentina. Journal of Arid Environments 36, 343-357.

Puig, S., Videla, F., Cona, M.I. and Monge, S.A. (2001) Use of food availability by guanacos (Lama guanicoe) and livestock in Northern Patagonia (Mendoza, Argentina). Journal of Arid Environments 47, 291-308.

Reddy, L.V., Metzger, R.J. and Ching, T.M. (1985) Effect of temperature on seed dormancy of wheat. Crop Science 25, $455-458$.

Rice, W.R. (1989) Analyzing tables of statistical tests. Evolution 43, 223-225.

Robertson, A.W., Trass, A., Ladley, J.J. and Kelly, D. (2006) Assessing the benefits of frugivory for seed germination: the importance of the deinhibition effect. Functional Ecology 20, 58-66.

Rodríguez-Pérez, J., Riera, N. and Traveset, A. (2005) Effect of seed passage through birds and lizards on emergence rate of Mediterranean species: differences between natural and controlled conditions. Functional Ecology 19, 699-706.

Rossi, B.E. and Villagra, P.E. (2003) Effects of Prosopis flexuosa on soil properties and the spatial pattern of understory species in arid Argentina. Journal of Vegetation Science 14, 543-550.

Samuels, I.A. and Levey, D.J. (2005) Effects of gut passage on seed germination: do experiments answer the question they ask? Functional Ecology 19, 365-368.

Smith, L.L. and Ueckert, D.N. (1974) Influence of insects on mesquite seed production. Journal of Range Management 27, 61-65.

Traveset, A. (1999) The importance of mutualisms for biodiversity conservation in insular ecosystems. Revista Chilena de Historia Natural 72, 527-538.

Traveset, A. and Richardson, D.M. (2006) Biological invasions as disruptors of plant reproductive mutualisms. Trends in Ecology and Evolution 21, 208-216.

Traveset, A. and Riera, N. (2005) Disruption of a plantlizard seed dispersal system and its ecological consequences on a threatened endemic plant in the Balearic Islands. Conservation Biology 19, 421-431. 
Traveset, A. and Verdú, M. (2002) A meta-analysis of the effect of gut treatment on seed germination. pp. 339-350 in Levey, D.J.; Silva, W.R.; Galetti, M. (Eds) Seed dispersal and frugivory: ecology, evolution and conservation. Wallingford, CABI Publishing.

Traveset, A., Robertson, A.W. and Rodríguez-Pérez, J. (2007) A review on the role of endozoochory in seed germination. pp. 78-103 in Dennis, A.J.; Green, R.J.; Schupp, E.W.; Westcott, D.A. (Eds) Seed dispersal: theory and its application in a changing world. Wallingford, CABI Publishing.

Varela, O. (2004) Frugivoría y dispersión de semillas por 13 especies de vertebrados en el Chaco salteño, Argentina. Doctoral thesis, Universidad Nacional de Córdoba, Argentina.
Verdú, M. and Traveset, A. (2005) Early emergence enhances plant fitness: a phylogenetically controlled meta-analysis. Ecology 86, 1385-1394.

Villagra, P.E., Marone, L. and Cony, M.A. (2002) Mechanisms affecting the fate of Prosopis flexuosa (Fabaceae, Mimosoideae) seeds during early secondary dispersal in the Monte Desert, Argentina. Austral Ecology 27, 416-421.

Zar, J.H. (1984) Biostatistical analysis (2nd edition). Englewood Cliffs, New Jersey, Prentice-Hall.

Received 12 June 2007

accepted 22 January 2008

(C) 2008 Cambridge University Press 